Stygofauna of the Canary Islands, 1

\title{
A NEW SPECIES OF PYGOCRANGONYX, AN AMPHIPOD GENUS WITH AFRICAN AFFINITIES, FROM FUERTEVENTURA
}

\author{
by \\ JAN H. STOCK \& BRIGITTE L. M. RONDÉ-BROEKHUIZEN \\ Institute of Taxonomic Zoology, University of Amsterdam, \\ P.O. Box 20125, 1000 HC Amsterdam, The Netherlands
}

\begin{abstract}
A group of exclusively subterranean Amphipoda, the Metacrangonyx group, is distributed mainly in northwestern Africa, with peripheral isolates on the Balearic Islands and in the Sinai desert.

The discovery of a new species of this group, belonging to Pygocrangonyx, a genus known from N.W. Morocco only, on Fuerteventura (one of the eastern Canary Islands) is of great biogeographic interest since it supports the theory that this island is of continental rather than oceanic origin.
\end{abstract}

\section{RESUMEN}

Un grupo de Amphipoda exclusivamente subterraneo, el grupo Metacranogonyx, tiene su distribución principalmente en el noroeste de Africa, con áreas aisladas periféricas en las Baleares y en el Sinaí.

El descubrimiento de una nueva especie de este grupo, perteneciente a Pygocrangonyx, un género conocido solamente en el noroeste de Marruecos, en Fuerteventura (una de las islas orientales de las Canarias), es de gran importancia biogeográfica que apoya la teoría de que esta isla es de origen continental más bien que oceánico.

\section{INTRODUCTION}

The geological history of the Canary Islands is still rather confused (Schmincke, 1976), although it is rather generally agreed upon that the western part of the archipelago is of purely oceanic origin, whereas the eastern islands (also called the Purpurarian group), or at least the island of Fuerteventura, has certain continental features, which may indicate that this island, or group of islands, are fragments of the African plate which drifted to deeper waters.

Biogeographic evidence points in the same direction (Evers et al., 1970), especially fossil records of land turtles and cursorial birds. Conclusions based on Recent terrestrial animals and plants are seriously hampered by the great human influence on the insular terrestrial habitats during the last few centuries. Likewise, it is hard to draw conclusions from the epigean freshwater biotas, because (1) permanent surface waters are rare and (2) where present they are heavily used for irrigation and drinkingwater supply. One of the least disturbed habitats is no doubt the groundwater, but with the exception of the detailed work in the Jameos de Agua (an anchihaline lava tunnel in Lanzarote, see Wilkens \& Parzefall, 1974; Valdecasas, 1985) the stygofauna of the Canary Islands remained completely unstudied.

It is our purpose to fill this gap in our knowledge by systematic sampling of suitable biotopes. We intend to present our results in a series of articles, the first parts of which will remain restricted to a taxonomic reconnaissance of a number of stygobiont organisms found in the islands. Hopefully some conclusions can be drawn as to the origin of the islands (and the origin of their stygofaunas) in a later phase of this study.

\section{MATERIAL AND METHODS}

Sampling of the stygofauna has been done using the following methods:

(1) In wells with a Cvetkov self-closing vertical net (mesh size $300 \mu \mathrm{m}$ ) (see Bou, 1975).

(2) In littoral and cave sediments (sand, gravel, pumice) with the Karaman-Chappuis method (see Delamare Deboutteville, 1960: 21) or by washing sediments (see Wilson, 1932: 6). 
(3) In caves and galleries for water supply with hand nets (mesh size $300 \mu \mathrm{m}$ ) and baited traps.

The samples obtained are preserved in toto in $4 \%$ neutralized formalin, later sorted under a dissecting microscope, and the sorted organisms are transferred into alcohol for further study.

In the field, the conductivity $(\mathrm{mS} / \mathrm{cm})$ and temperatures are measured directly with a WTW-LF-91 field-meter, and the salinities with an American Optical refractometer model 10419.

During a three-weeks programme (May 1985) groundwaters of three islands in the eastern part of the Canary archipelago have been sampled. The total eastern group (the Purpurarians) counts seven islands of some size, of which Graciosa $(N=5)$, Lanzarote $(N=105)$ and Fuerteventura $(N=53)$ were visited $(N$ is the number of samples taken in stygal habitats). Figs. 2 and 3 show the distribution of the samples over the islands. Not visited were Alegranza, Roque del Este, Montaña Clara and Lobos, the four smallest islands of the Purpurarian group (fig. 1). The map reference provided in the locality lists is based on the Universal Transverse Mercator (UTM) grid of the Mapa Militar de España, 1:50,000.

Different types of stygal habitats are not equally distributed over the three islands sampled during the present study. This fact is stressed here because our study showed important taxonomic differences between Fuerteventura on the one hand and Lanzarote plus Graciosa on the other. These differences may be due to a different geological history of these islands, but it is not excluded that habitat differences play a role as well.

The following habitats may be distinguished; the frequency of their occurrence on the islands sampled is indicated as well ( $\mathrm{F}=$ Fuerteventura; $\mathrm{G}=$ Graciosa; $\mathbf{L}=$ Lanzarote):

(1) Deep wells, reaching the phreatic (permanently saturated) level, depths frequently over $10 \mathrm{~m}$, sometimes $>40 \mathrm{~m}$ (very abundant in $\mathrm{F}$, rare in $\mathrm{L}$, absent in $\mathrm{G}$ ).

(2) Deep 6-inch drill holes, reaching the phreatic level (depth $>40 \mathrm{~m}$ ) (some in L).

(3) Shallow wells, usually gathering superficial (be it subterranean) run-off of rain and dew, but not reaching the permanently saturated level; the water is captured in cistern-like basins, often square and cemented, less than a few metres in depth (abundant in L and G, rare in F).

(4) Man-made tunnels, sometimes spring-fed, used for water supply (some in L).

(5) Windpumps used for pumping seawater into saliñas, via subterranean tunnels; nowadays, these windpumps and tunnels are no longer in use; depth up to some $10 \mathrm{~m}$ (only in L).

(6) Lava tunnels and lava caves, the former anchihaline (only in L).

(7) Resurgences (anchihaline) of seawater in pools at some distance from the shoreline (some in L).

(8) Interstitia of sand, gravel and pumice of beaches, anchihaline pools and barrancos (= temporal torrents) (in $\mathrm{L}$ and $\mathrm{F}$ ).

\section{THE TAXONOMY OF THE METACRANGONYX GROUP}

The present paper deals with a member of the Metacrangonyx group discovered in Fuerteventura. The taxonomic position of this group is still uncertain. Originally (Chevreux, 1909) Metacrangonyx was considered related to Eucrangonyx and to a lesser extent to Gammarus, both at that time members of the Gammaridae.

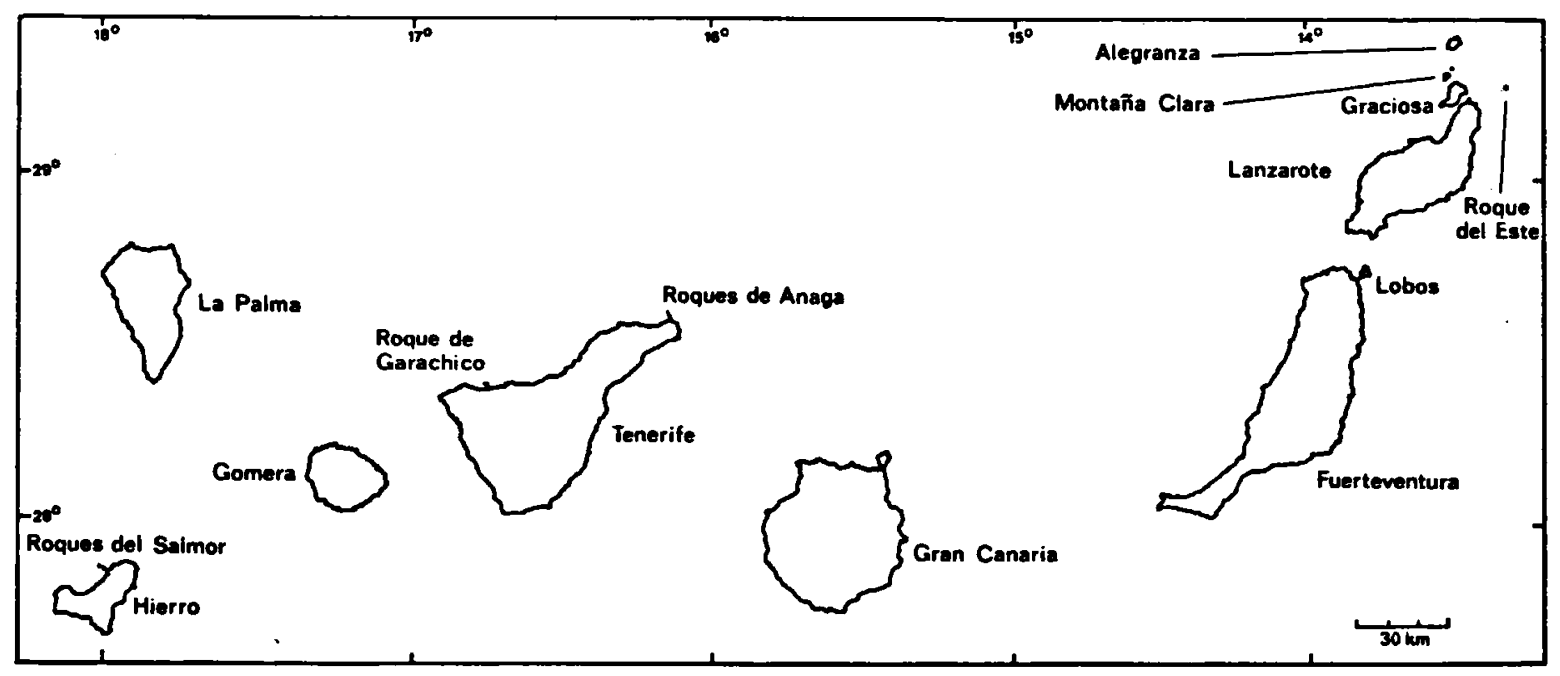

Fig. 1. The Canary Islands (source: Symposium "Herpetologia Canariensis”, Bonn. zool. Beitr., 36: 233, 1985). 


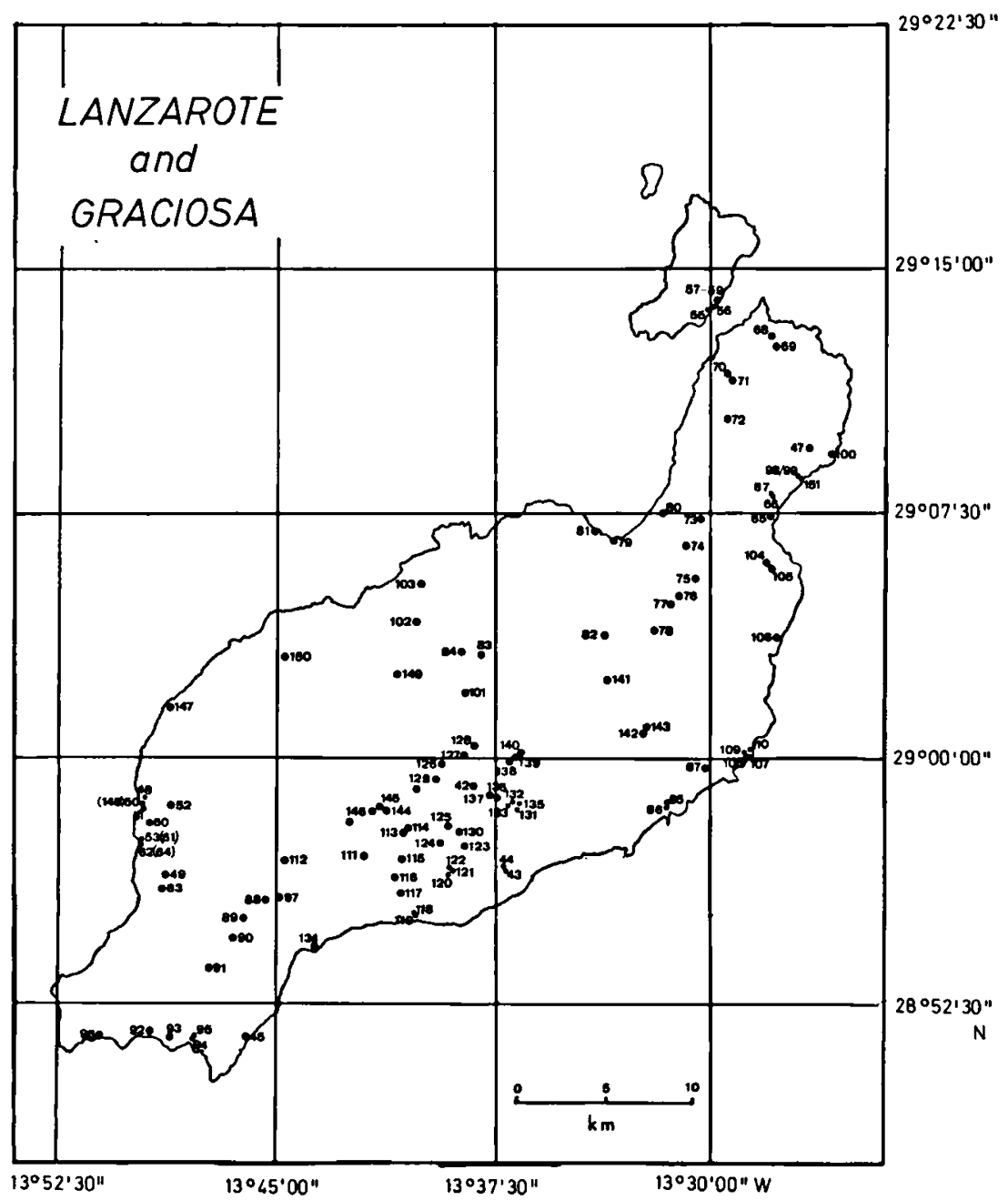

Fig. 2. Distribution of stygofauna samples taken during 1985 in Lanzarote and Graciosa.

Schellenberg (1937) stressed its relationship with Crangonyx, but Bousfield (1977, 1982) removed it from the crangonyctoids and placed it in the family Hadziidae, with which it shares numerous features in the antennae, mouthparts and gnathopods. On the other hand, Stock (1977) judged the shortening of uropod 3 and in particular the uncleft telson of Metacrangonyx important enough to prevent a position within the hadzioids. Recently, Boutin \& Messouli (in press) have proposed a new family, Metacrangonyctidae, related to (but wellseparable from) the hadzioids, to receive the four genera and eight species grouped around Metacrangonyx.
The validity of the four genera distinguished so far (Karaman, 1981; Boutin \& Messouli, in press) has been subjected to considerable doubt, expressed in particular by Ruffo (1983). Boutin \& Messouli follow Ruffo in synonymizing Afrocrangonyx Karaman, 1981, with Metacrangonyx Chevreux, 1909, and added a new genus, Pachypodacrangonyx. A cladistic analysis (vide infra) of the Metacrangonyx group shows that only one of the species attributed to Afrocrangronyx, $A$. longicaudus (Ruffo, 1954) shows an autapomorphy, all others show at most a number of synapomorphies. The members of Afrocrangonyx even do not come out as a single branch, but as a scattered cluster in 


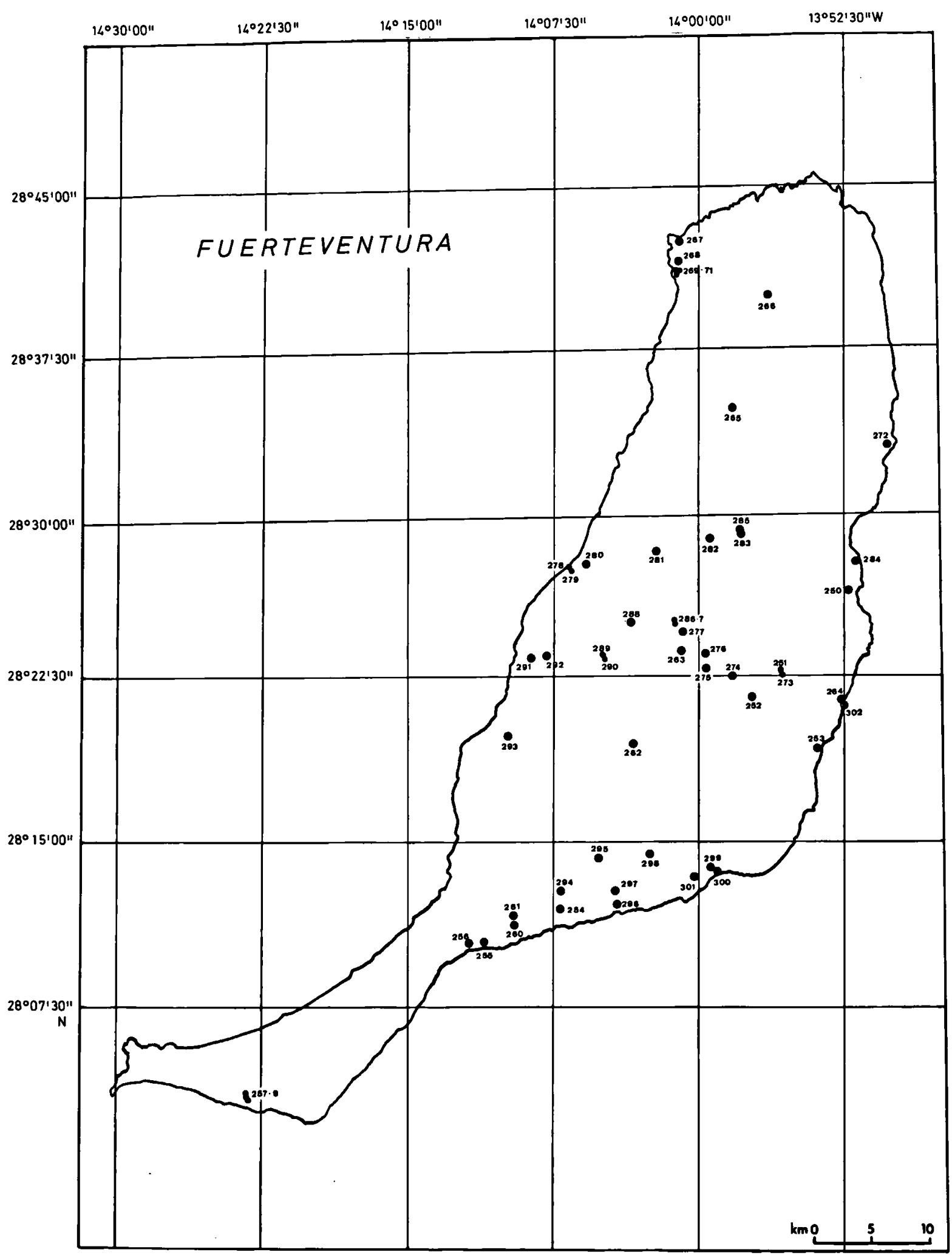

Fig. 3. Distribution of stygofauna samples taken during 1985 in Fuerteventura. 
the cladogram. This seems to confirm Ruffo's and Boutin \& Messouli's opinion that the genus Afrocrangonyx is a poorly characterized unit.

Pygocrangonyx Karaman \& Barnard, 1979, is close as well, and is distinguished in Ruffo's opinion by the absence of an endopodite in uropod 3 only. In addition, however, this genus is characterized by the autapomorphous condition of the accessory flagellum of the first antenna, which is 2-segmented against 3- to 5segmented in all other taxa of the group.

The degree of lobation of the basis of pereiopods 5 to 7, used by Karaman (1981) as one of the diagnostic characters to distinguish the genera of the Metacrangonyx group, is considered by us of too little importance: Metacrangonyx (or Afrocrangonyx) sinaicus Ruffo, 1983 has poorly developed lobes, whereas the other species of these genera have strong lobes; similarly, Pygocrangonyx remyi (Balazuc \& Ruffo, 1954) has poorly developed lobes, whereas the lobes are much better developed in the new Pygocrangonyx from the Canary Islands. Similar variations in the lobation of the basis of P5 to P7 are sex and age dependent in an outgroup of Metacrangonyx, the genus Pseudoniphargus.

The Metacrangonyx group is mainly distributed in northwestern Africa (maps in Karaman, 1981, and in Boutin \& Messouli, in press), with two peripheral isolates, viz. in Mallorca and Menorca (Balearic Islands) (refs. in Karaman, 1981) and in the Sinai desert (Ruffo, 1983).

\section{Pygocrangonyx repens n. sp.}

Material. - One male, holotype. Sta. 85-289, Fuerteventura, Vega de Río Palmas, open well (UTM coordinates ES $059155 \times 314105)$; ovate well with windpump, water level at $20 \mathrm{~m}$, water depth $1 \mathrm{~m}$, salinity 5.5 ppt, 27 May 1985 (ZMA Amph. 108.014).

One female (allotype). Sta. 85-281, Fuerteventura, El Cigarrón (=W. of Llanos de la Concepción), open well of Finca no. 714 (UTM coordinates ES $059324 \times 315070$ ), with windpump, water level at $10 \mathrm{~m}$, water depth $3.5 \mathrm{~m}$, salinity 4.5 ppt, 26 May 1985 (ZMA Amph. 108.015).

One male (paratype). Sta. 85-280, Fuerteventura, open well in Barranco del Crangejo, ca. $500 \mathrm{~m}$ from the sea (UTM coordinates ES $058760 \times 314910$ ), ruined windpump, water level at $4 \mathrm{~m}$, water depth $5 \mathrm{~m}$, salinity $8 \mathrm{ppt}$, 26 May 1985 (ZMA Amph. 108.016).
Description. - Blind, unpigmented. Body length of the 3 specimens: $2.7 \mathrm{~mm}$ (paratype), $3.7 \mathrm{~mm}$ (allotype) and $4.0 \mathrm{~mm}$ (holotype). Body not very slender, legs rather short (fig. 4a). Antennal sinus small but distinct. Most body segments (except for urosomite 3) with some short dorsal setules.

First antenna (figs. 4b, 9a) less than half as long as body. Peduncle segment 2 slightly shorter than 1, segment 3 much shorter than 2. Accessory flagellum (fig. 4c) shorter than first flagellum segment, 2-segmented; basal segment elongate and slender, distal segment minute. Flagellum 10-segmented; aesthetasks on segments 2 to 9 , each about half as long as corresponding flagellum segment.

Second antenna (fig. 5a) with long, slender gland cone. Flagellum 6- or 7-segmented, no calceoli. Peduncle segments 4 and 5 of female less slender than in male (figs. $5 \mathrm{a}, 5 \mathrm{~b}$ ).

Upper lip (fig. 4d) tongue-shaped, distal margin with short setules.

Mandible with short palp, 1- or 2-segmented (the holotype has a 1-segmented palp on the right mandible and a 2-segmented palp left; the allotype has left and right a 1-segmented palp) (figs. 6c, d, e). The mandibles are asymmetrical: the left lacinia mobilis (fig. 6a) consists of 1 prong, armed with 4 medial teeth (thus, including the distal tooth, 5-dentate); the right lacinia (fig. 6b) is bifid, one cusp finely toothed, the other with 3 coarser teeth. Between lacinia and molar there are 6 longer and 6 shorter setae (left) or 5 longer and 4 shorter setae (right). Molar seta present on both sides, short on left molar, long on right molar.

Lower lip (fig. 4e) without inner lobes.

First maxilla (fig. 4f): Inner lobe elongate ovate, with medial row of ca. 14 plumose setae. Outer lobe with 11 distal spines (fig. $4 \mathrm{~g}$ ); the medial margin of these spines, from lateral to medial, with 4 to 8 denticles. Palp 2-segmented, left palp with 3 spines and 2 setae, right palp with 4 spines and 2 setae; left palp, and its spines, slightly more slender than those of right side (figs. $4 \mathrm{~h}, \mathrm{i}$ ).

Second maxilla (figs. 5c, d): Inner lobe with diagonal row of setae. 


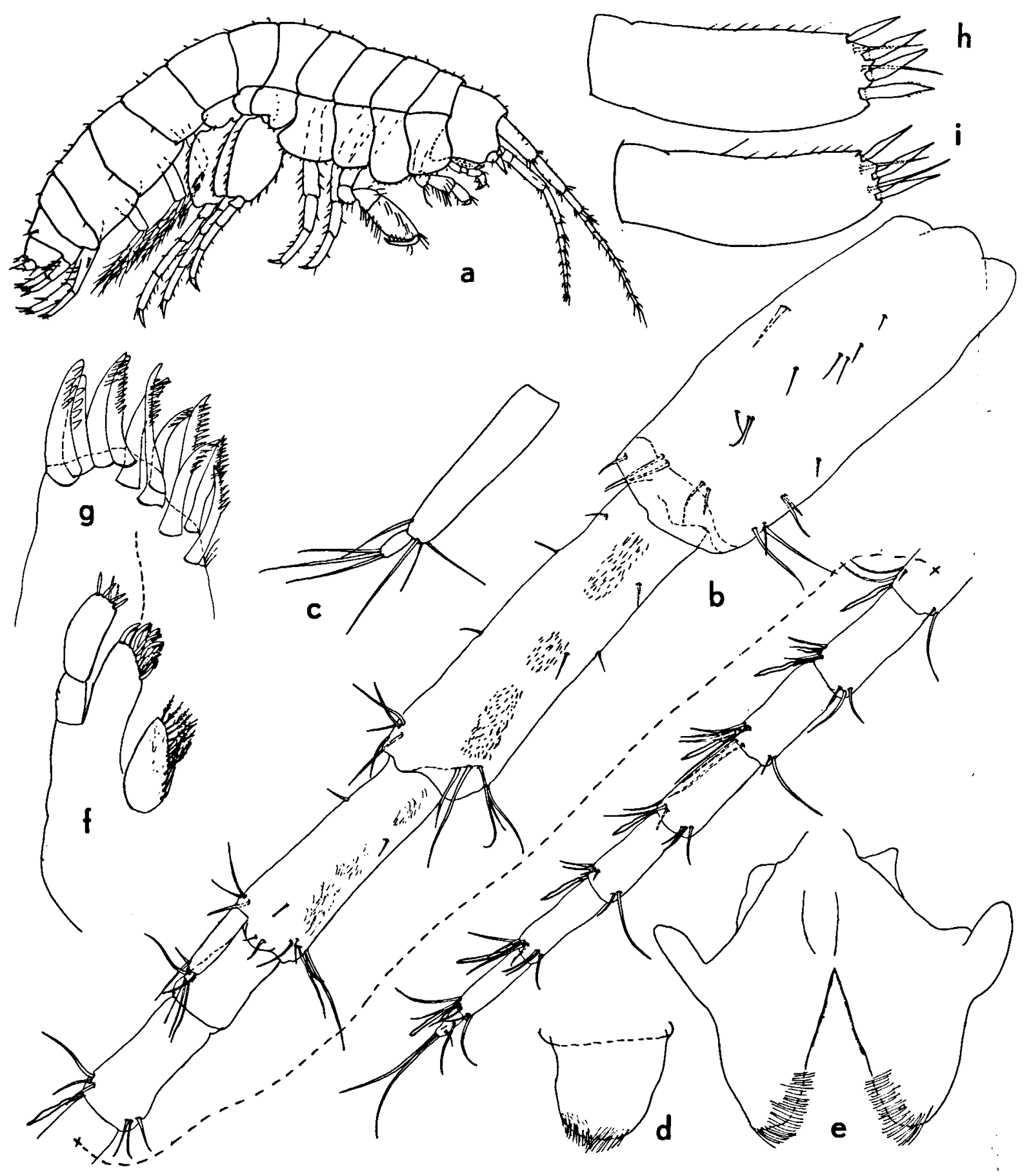

Fig. 4. Pygocrangonyx repens $n$. sp.: a, male, from the right (actual length $4 \mathrm{~mm}$ ); b, first antenna, $\bigcirc$ (scale $A C$ );

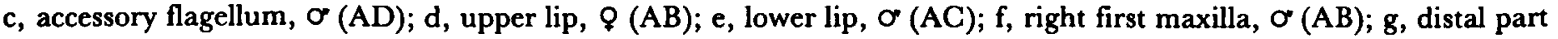
of outer lobe of first maxilla, $\sigma$ (AE); $h$, second segment of right palp of first maxilla, $Q$ (AD); i, same of left palp, Q (AD). Scales on fig. 7. 


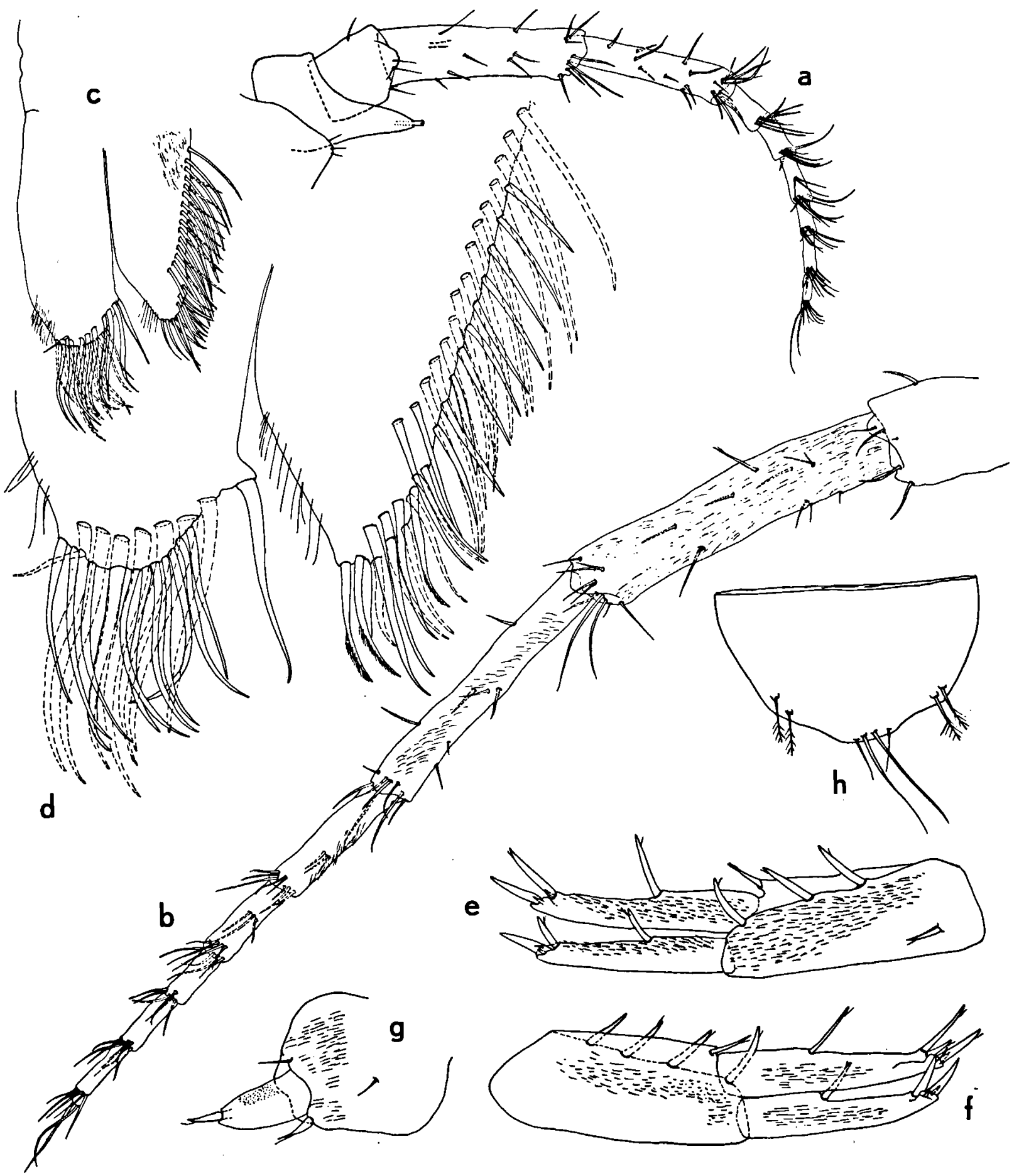

Fig. 5. Pygocrangonyx repens $\mathrm{n}$. sp.: a, second antenna, $९$ (scale AB); b, second antenna, $\sigma^{\prime}$, basal segments omitted (AC); c, second maxilla, $\sigma^{\circ}(\mathrm{AC})$; d, distal part of inner and outer lobes of second maxilla, $\sigma^{\circ}$ (AE); e, first uropod, $\sigma^{\circ}$ (AB); f, second uropod, $\sigma^{\prime}(\mathrm{AB}) ; \mathrm{g}$, third uropod, $\sigma^{\circ}(\mathrm{AC})$; h, telson, $९$ (AD). Scales on fig. 7. 
Maxilliped (figs. 6f-i): Outer and inner lobes long. Inner lobe with 3 distal spines, the shape of which is somewhat variable, sometimes all spines are molar-shaped, sometimes one of the spines is leaf-shaped (figs. 6g-h). Outer lobe with ca. 9 lanceolate spines. Palp as illustrated.

First gnathopod (figs. 7a-c): Coxal plate about $13 / 4$ times as long as wide; inferior margin with several setules. Anterior margin of basis with 1 to 3 setules, posterior margin with 3 to 5 long setae. Merus with patch of rugosities. Carpus longer than propodus, but less elongate than in Metacrangonyx; posterior margin with 3 to 4 groups of setae. Propodus rectangular in outline; palmar corner with 3 bicuspidate spines. Outer margin of claw with 1 seta. No sexual dimorphism.

Second gnathopod sexually dimorphic in propodus and claw (figs. 8a-d). Coxal plate, basis and ischium comparable with those of Gn1. Carpus more or less triangular. Propodus of male larger, posterior margin shorter, and setae on posterior margin shorter, palmar margin and claw longer than those in female. Palmar margin armed with 2 rows of bicuspidate spines, ca. 10 pairs in male, ca. 7 pairs in female; no differentiated palmar angle spines. Claw with 2 outer setae in female, 1 in male.

Coxal gills with short, narrow stalk; gill blade ovate to sausage-shaped; gills present on Gn2 and P3 through P6. No sternal gills.

Third pereiopods of male and female (figs. $9 b-c)$ practically identical. Merus of male more densely covered with minute spinules.

Oostegites linear, distal half with long setae; present on P3 through P5.

Fourth pereiopod (figs. 10a-b) similar to third. Coxal plate with large, shallow posterior emargination.

Fifth pereiopod (figs. 11a, 12a) with anterolobate coxal plate. Basis roughly ovate. Patches of minute spinules abundant in male, scarce in female. Propodus of male slightly more elongate than that of female.

Sixth pereiopod (figs. 11b-c) longer than fifth. Basis more elongate in shape, other segments resembling those of P5. Sexual dimorphism comparable to that in $\mathrm{P} 5$.
Seventh pereiopod (figs. 12b-c) hardly longer than sixth. Coxal plate with small anterior lobe, other segments similar to those of P6. More spinulose patches in male than in female, but distal segments of female P7 lacking.

Pleopods 1 to 3 (figs. 10c-e) biramous; pedunculus with 3 (!) retinacula. Most proximal of medial elements of each pleopodal endopodite assuming shape of clothespeg spine; all other elements setiform. No sexual dimorphism.

Epimeral plates 1 to 3 (fig. 11d) ending in small ventroposterior tooth; ventral margins unarmed, posterior margins with 1 setule.

Peduncle of uropod 1 (figs. 5e, 7d) with strong ventroproximal spine. Exopodite slightly shorter than endopodite; each ramus with 1 mediodorsal spine. Patches of minute spinules larger in male than in female.

Peduncle of uropod 2 of female shorter than in male (figs. 5f, 7e). Exopodite shorter than endopodite.

Uropod 3 strongly shortened (figs. $5 g, 7 f$ ). Peduncle swollen, rounded. Peduncle on left side (but not on right side) of female with very long seta; no such seta in male. Exopodite shorter than peduncle, slightly tapering, armed with 1 strong distal spine only. Endopodite absent.

Telson (fig. 5h) 13/4 times as wide as long; no distal notch or cleft. A pair of plumose (sensorial) setules on either side. Two long and two short distomedial setae.

Remarks. - There are certain differences between the male holotype and the female allotype (e.g. in the length of the peduncle of uropod 2). We are unable to decide, from the small material at hand, if these differences are indicative of sexual dimorphism or of individual variation.

Distinction. - Only one species of Pygocrangonyx was hitherto known, viz. P. remyi (Balazuc \& Ruffo, 1953) from N.W. Morocco. The new species from Fuerteventura differs at first sight from $P$. remyi in the strong lobation of P5 to P7 and in the armature of the exopodite of uropod 3 (with 1 strong spine only, instead 


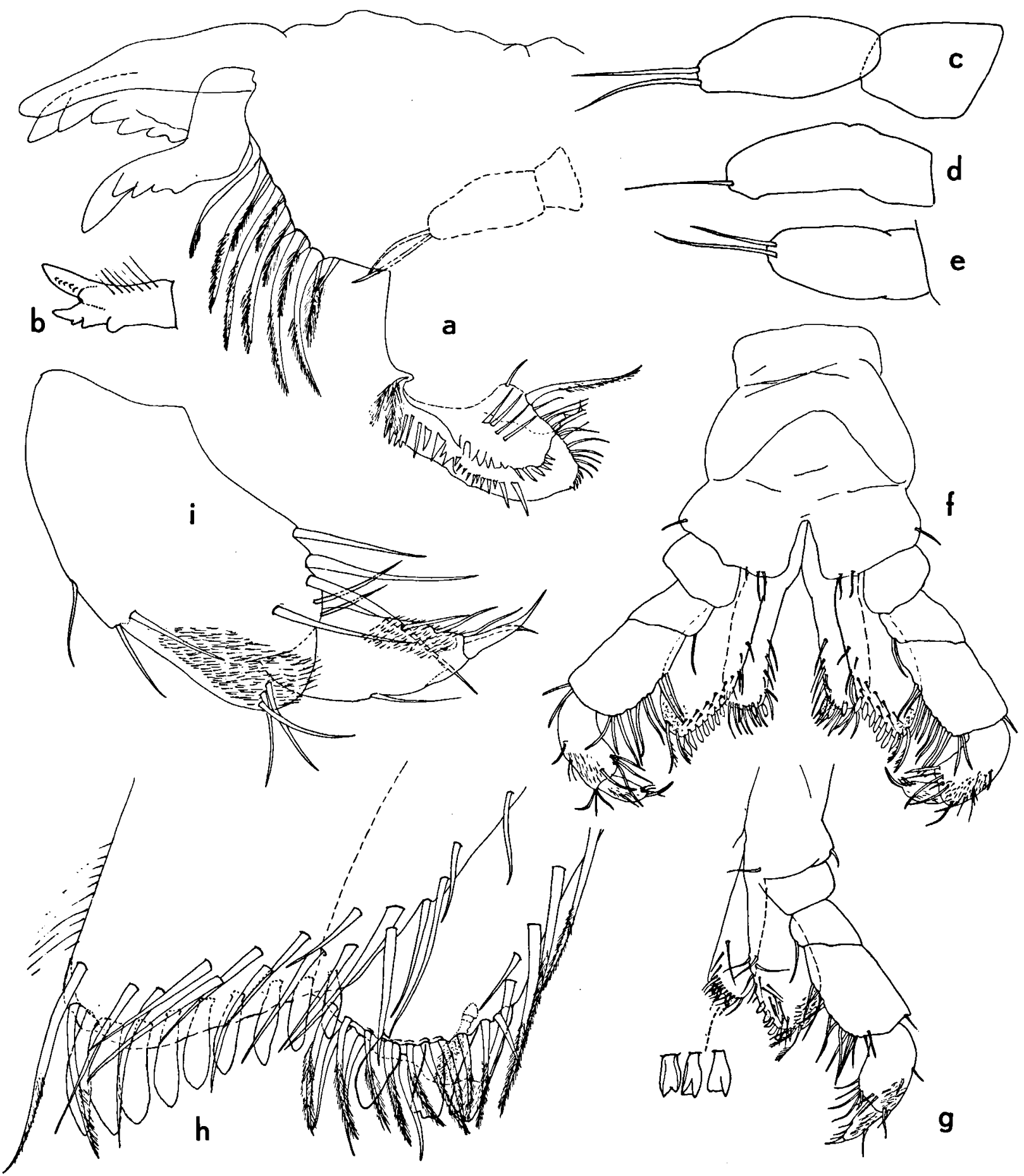

Fig. 6. Pygocrangonyx repens n. sp.: a, left mandible, $\sigma^{\circ}$ (scale AE); b, right lacinia mobilis, $\sigma^{\circ}$ (AE); c, palp of left mandible, $O^{\circ}(\mathrm{AE})$; d, e, right and left palp of mandible, $\$$ (AE); f, maxillipeds, $\%$ (AB); g, maxilliped, $\sigma^{*}(\mathrm{AB})$; h, distal part of inner and outer lobes of maxilliped, $९$ (AE); $i$, distal segments of maxillipedal palp, $\&$ (AE). Scales on fig. 7. 


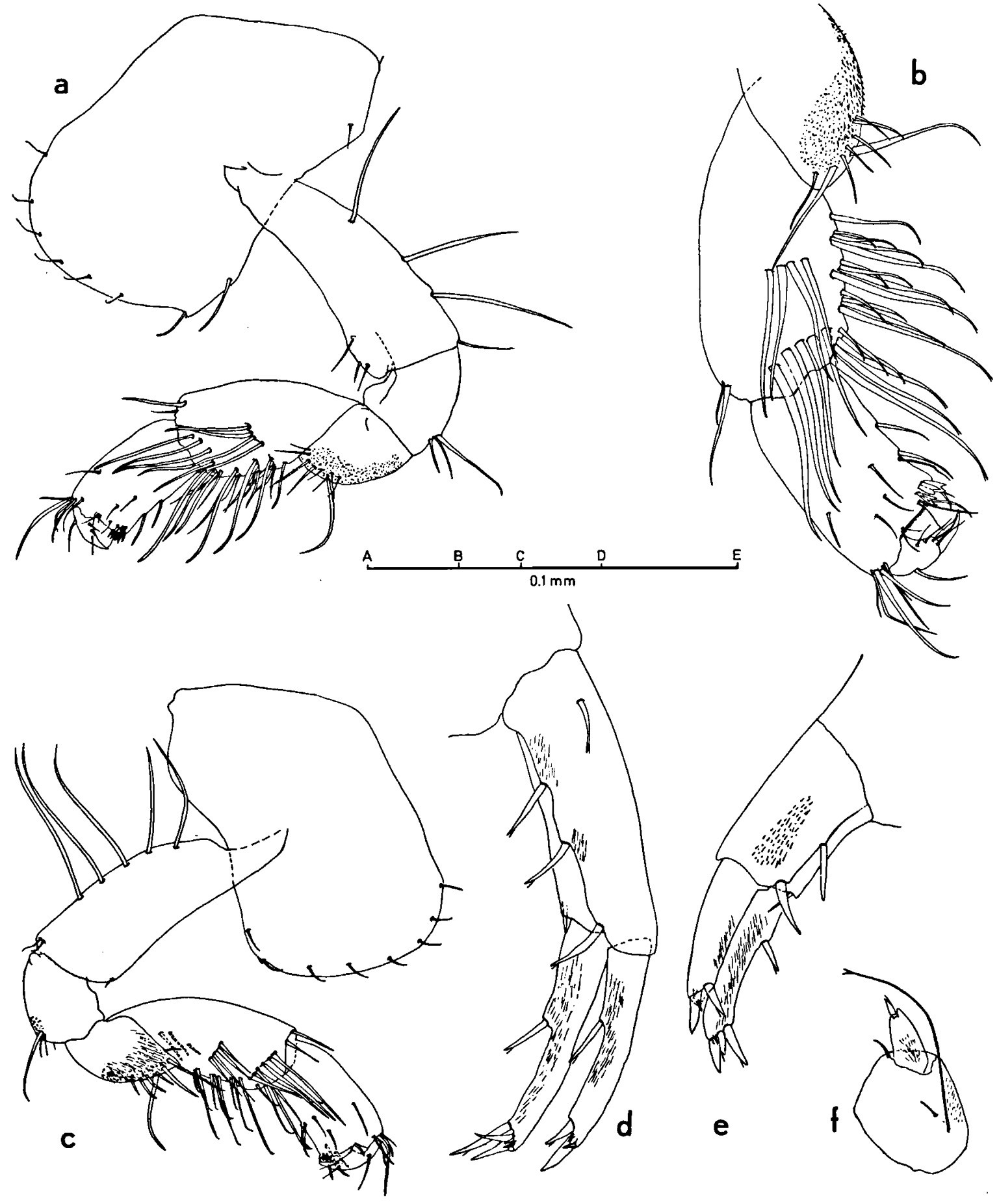

Fig. 7. Pygocrangonyx repens n. sp.: a, first gnathopod, $Q$ (scale AB); b, distal segments of first gnathopod, $९$ (AC); , first gnathopod, $\sigma^{\circ}(\mathrm{AB})$; d, first uropod, $\$(\mathrm{AB})$; e, second uropod, $\$(A B)$; $f$ third uropod, $\$$ (AB). Each scale portion (AB, AC...AE) represents $100 \mu \mathrm{m}$. 

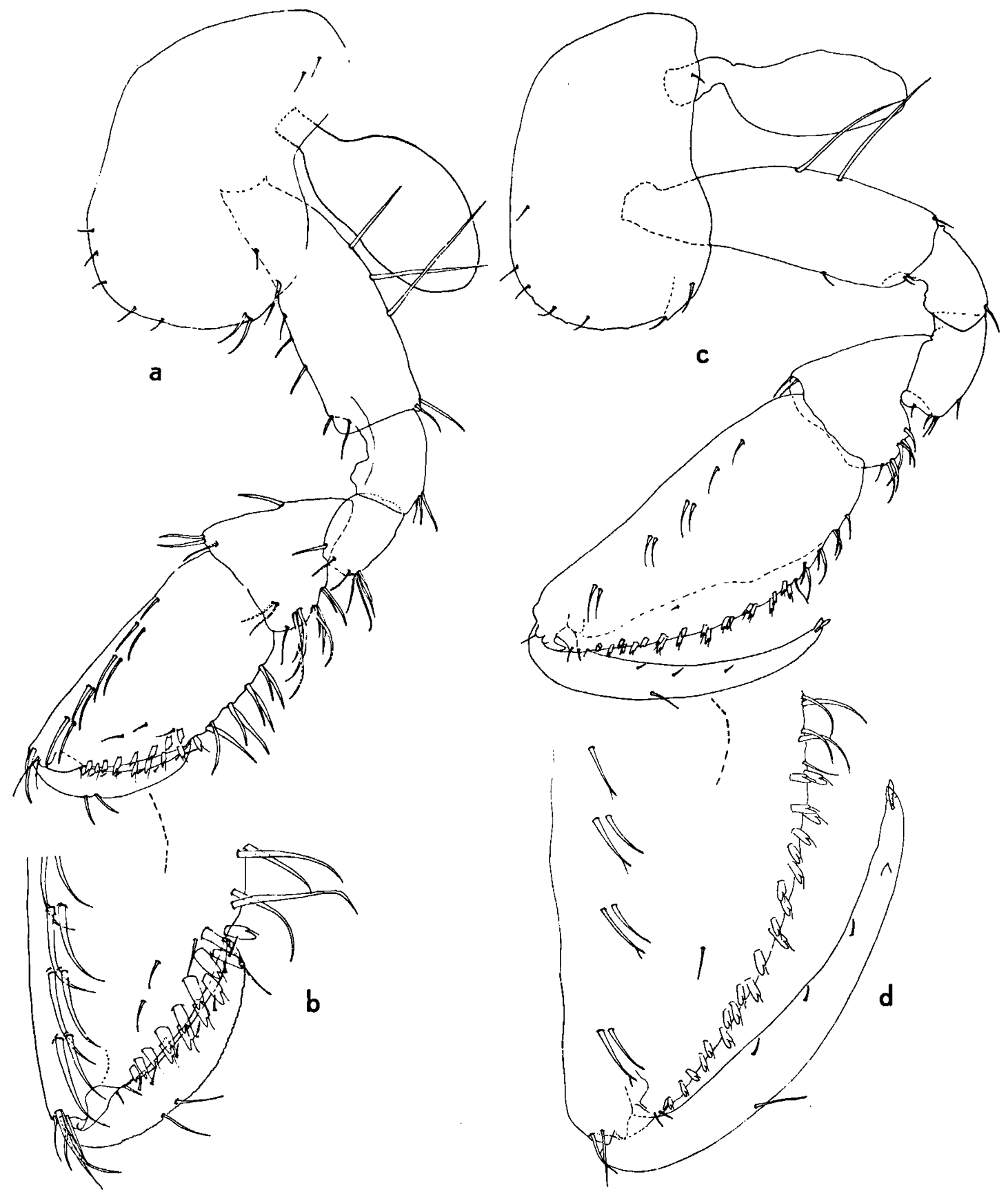

Fig. 8. Pygocrangonyx repens $\mathrm{n}$. sp.: a, second gnathopod, $९$ (scale PR); b, palma of second gnathopod, ९ (PS); c, second gnathopod, $\sigma^{\circ}(\mathrm{PR})$; d, palma of second gnathopod, $\sigma^{\circ}(\mathrm{PS})$. Scales on fig. 11. 


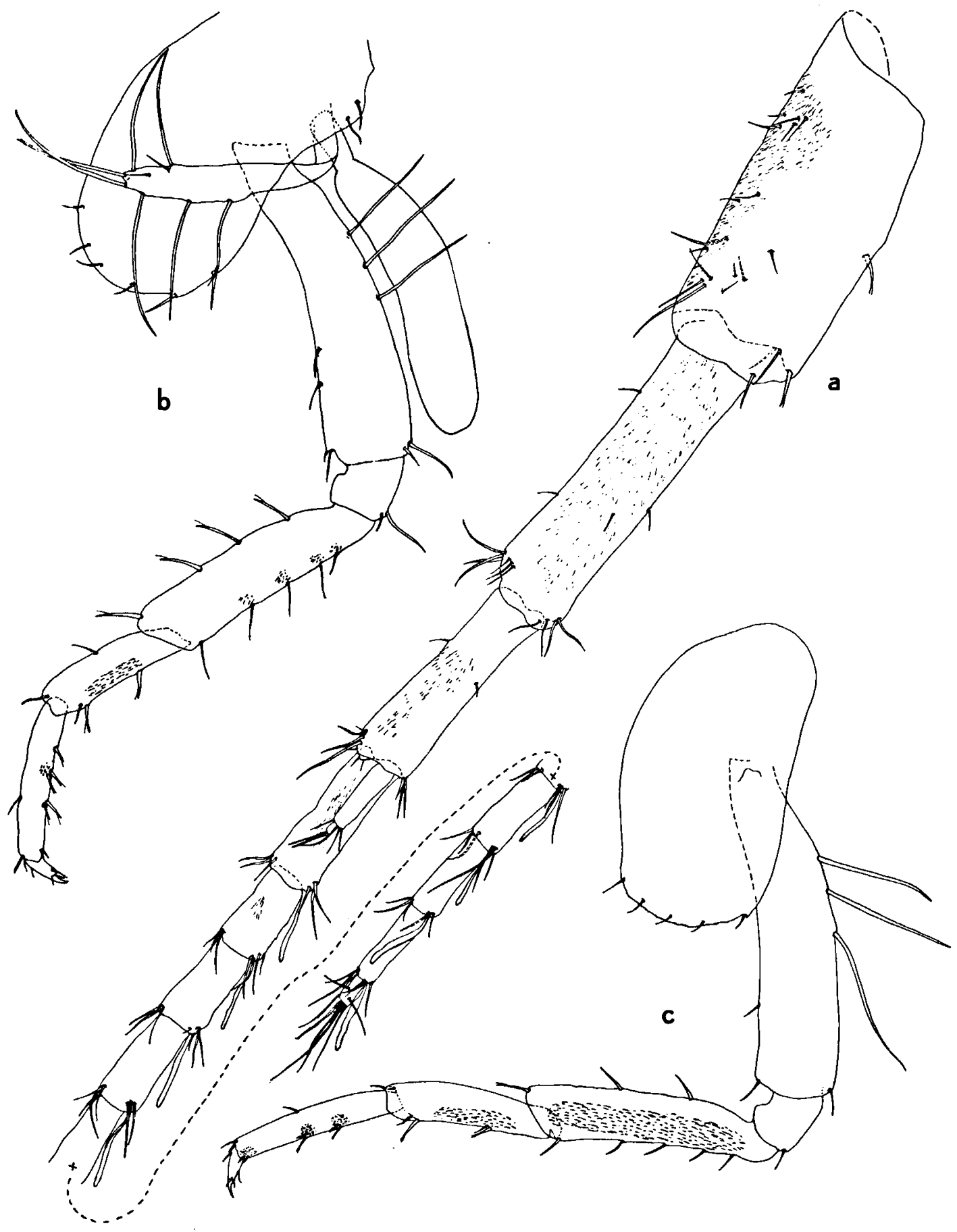

Fig. 9. Pygocrangonyx repens n. sp.: a, first antenna, $\sigma^{\circ}$ (scale PS); b, third pereiopod, $\$$ (PR); c, third pereiopod, O $^{\circ}(\mathrm{PR})$ Scales on fig. 11. 

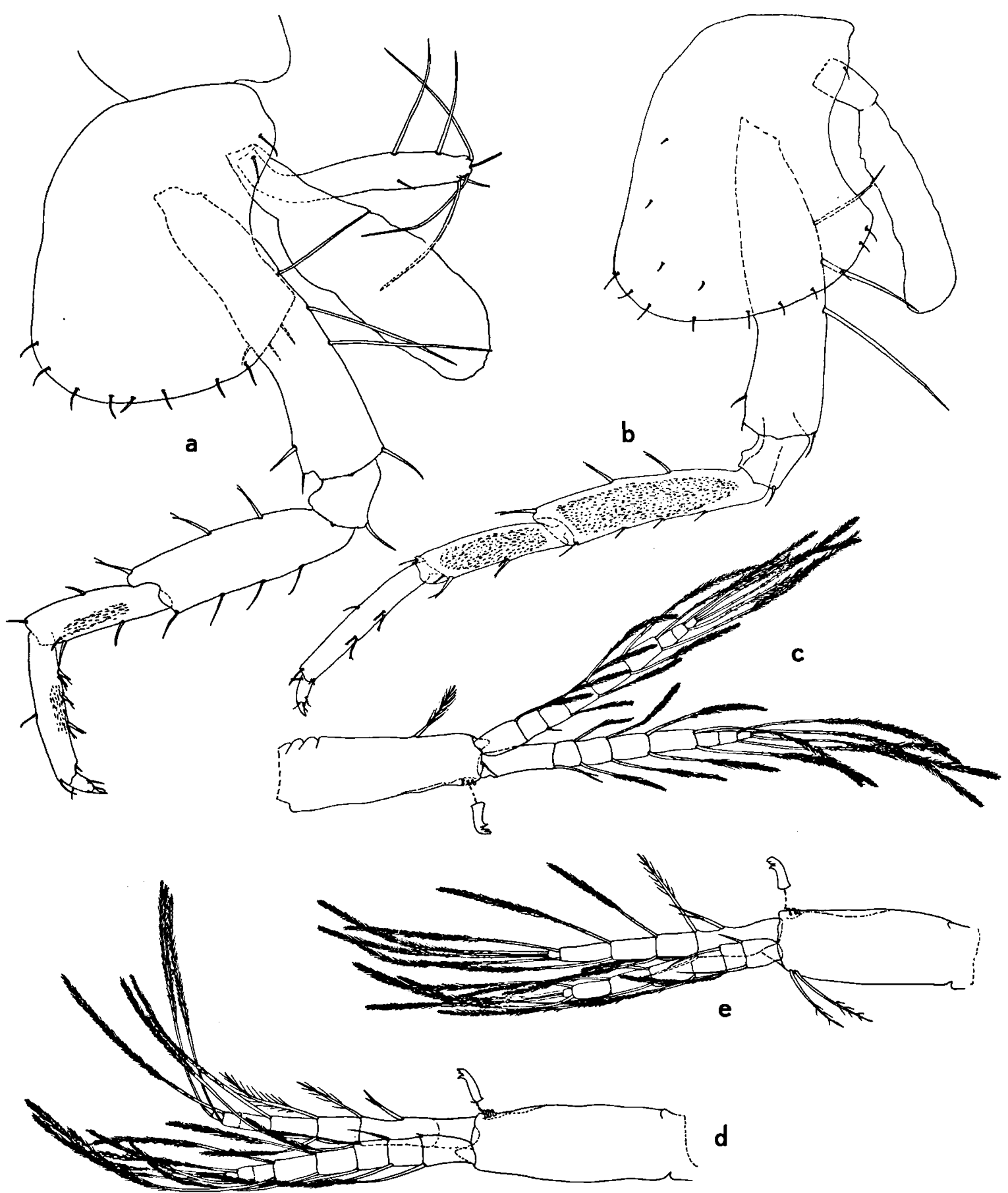

Fig. 10. Pygocrangonyx repens n. sp.: a, fourth pereiopod, \&; b, fourth pereiopod, $\sigma^{\circ}$; c, first pleopod, $\sigma^{\circ}$; d, second pleopod, o; e, third pleopod, ơ. All scale PR. Scales on fig. 11. 


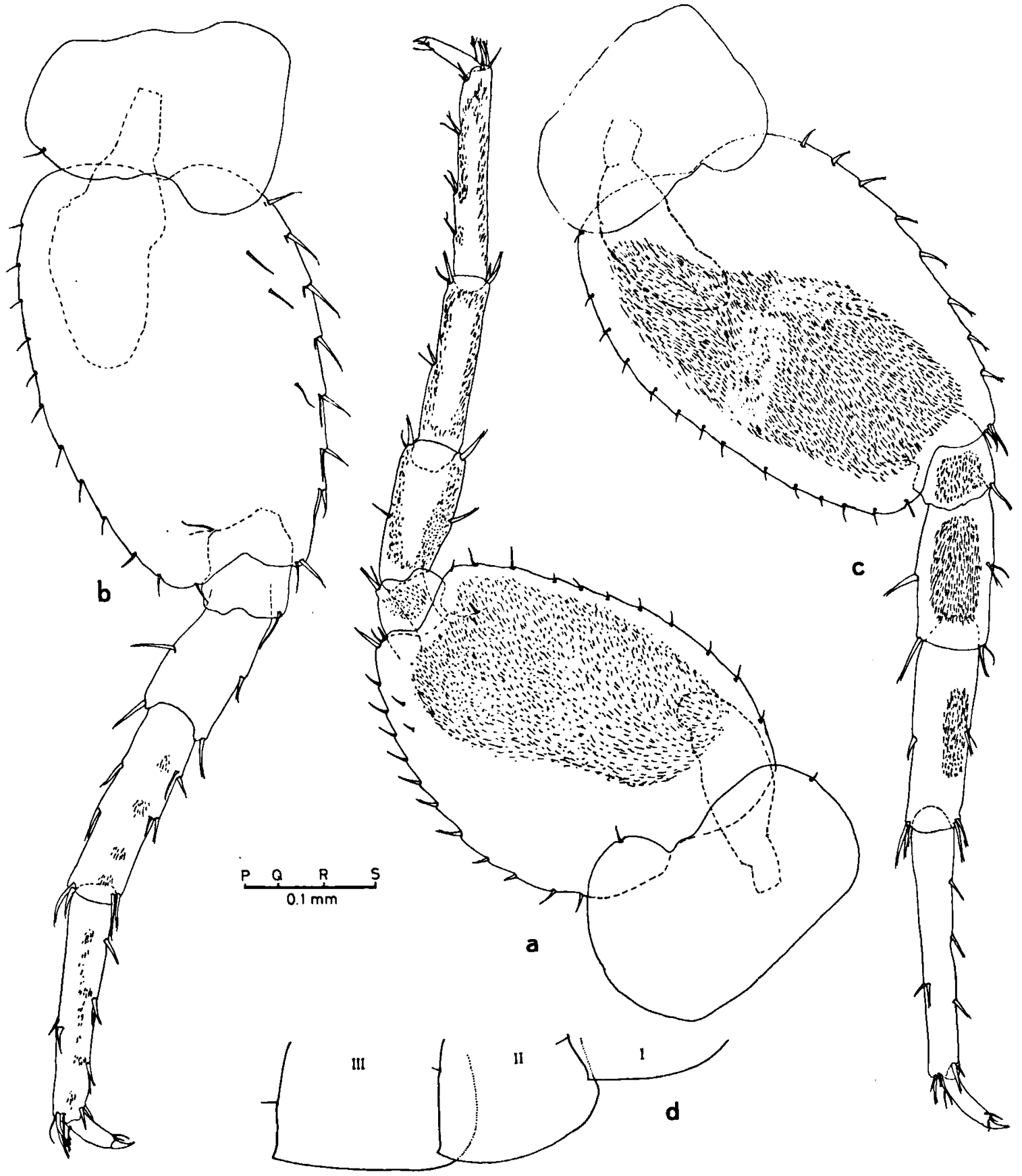

Fig. 11. Pygocrangonyx repens n. sp.: a, fifth pereiopod, $\sigma^{\circ}$ (scale PR); b, sixth pereiopod, $९$ (PR); c, sixth pereiopod, $\sigma(P R)$; d, epimeral plates I to III, from the right, $\sigma^{\circ}(P Q)$. Each scale portion (PQ PR, PS) represents $100 \mu \mathrm{m}$. 


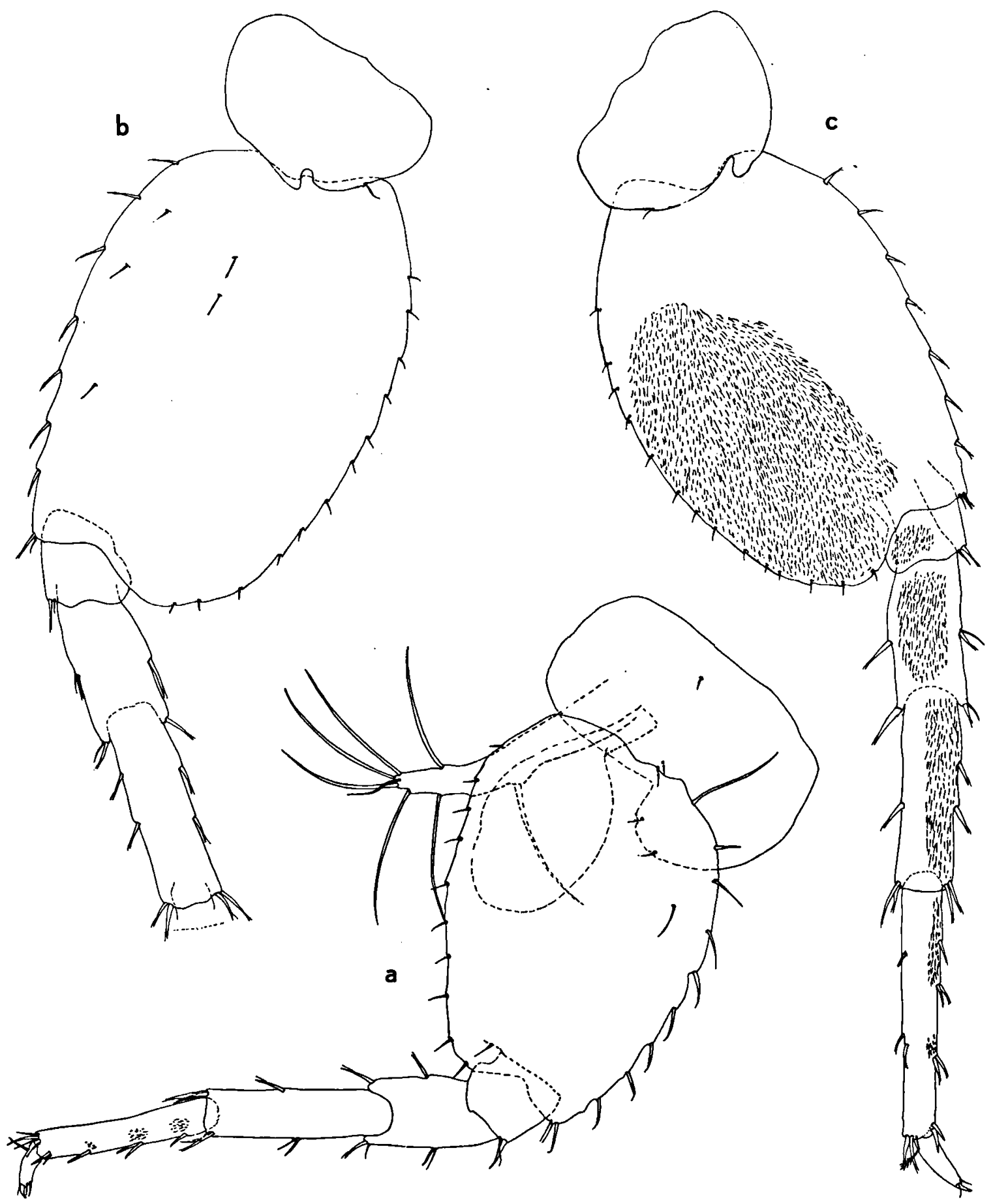

Fig. 12. Pygocrangonyx repens $\mathrm{n}$. sp.: a, fifth pereiopod, १; b, seventh pereiopod, \&; c, seventh pereiopod, $\sigma^{\circ}$. All scale PR. Scale on fig. 11. 
of with a bunch of several spines), etc. (cf. table III).

Etymology. - The specific name proposed, repens (Latin), meaning “'unexpected", alludes to the surprising insular occurrence of the new species.

\section{PHYLOGENY}

\section{The cladogram}

The genera of which the Metacrangonyx group is composed are, as is stressed by several authors (Karaman, 1981; Ruffo, 1983; Boutin \& Messouli, in press) very closely related, and form without any doubt a monophyletic group. All members share the apomorphic telson shape (uncleft, shortened) and apomorphic shortening of the third uropods by which they are distinguished from the related hadzioid group.

Table I lists 10 characters showing different states of plesio- and apomorphy in various species of the Metacrangonyx group. The decision whether a character state is plesio- or apomorphic is based on comparison with a sistergroup, the hadzioids, and an out-group, the gammaroids.

Table II lists the distribution of plesio- and apomorphic states over the taxa. As usual, this distribution shows a mosaic pattern. The table is based on personal observations of Metacrangonyx longipes Chevreux, 1909 (the typespecies of a monotypic genus), the typematerial of Afrocrangonyx longicaudus, $A$. panousei (Ruffo, 1953), A. spinicaudatus (Balazuc \& Ruffo, 1953), and - of course- the present specimens of Pygocrangonyx repens*. For the other taxa information was retrieved from the literature. A cladogram based on the data of table II is shown in fig. 13. "Metacrangonyx"

* The results of the re-examination of the type-material can be summarized as follows: all species of $A$ frocrangonyx lack a seta on the left molar; $A$. panousei has 5 teeth on the left lacinia mobilis, the two other species have 4 teeth; $A$. panouse $i$ has 3-4 retinacula on all pleopods, $A$. spinicaudatus has 2 retinacula, and $A$. longicaudus has 2 retinacula on pleopods 2 and 3 , but only 1 on pleopod 1 .
TABLE I

Ten character states used to distinguish the various N.W. African taxa of the Metacrangonyx group.

\begin{tabular}{|c|c|c|}
\hline & plesiomorphic & apomorphic \\
\hline $\begin{array}{l}\text { 1. Accessory } \\
\text { flagellum A1 }\end{array}$ & 3- to 5-segmented & 2-segmented \\
\hline $\begin{array}{l}\text { 2. Left lacinia } \\
\text { mobilis }\end{array}$ & 5-dentate & 4-dentate \\
\hline 3. Molar seta & $\begin{array}{l}\text { present on both } \\
\text { sides }\end{array}$ & $\begin{array}{l}\text { absent on left } \\
\text { molar }\end{array}$ \\
\hline $\begin{array}{l}\text { 4. Mandible } \\
\text { palp }\end{array}$ & $\begin{array}{l}\text { reaching to in- } \\
\text { cisor, visible } \\
\text { without dissection, } \\
3 \text {-segmented }\end{array}$ & $\begin{array}{l}\text { rudimentary, } \\
\text { invisible with- } \\
\text { out dissection, } \\
1 \text { - to } 3 \text {-seg- } \\
\text { mented }\end{array}$ \\
\hline 5. Palma Gn.2 & $\begin{array}{l}\text { straight, with } \\
\text { bifid spines }\end{array}$ & $\begin{array}{l}\text { concave, no } \\
\text { bifid spines }\end{array}$ \\
\hline 6. Coxal gills & stalk $\ll$ blade & stalk = blade \\
\hline $\begin{array}{l}\text { 7. No. of reti- } \\
\text { nacula }\end{array}$ & 3 or 4 & $<3$ \\
\hline $\begin{array}{l}\text { 8. No. of retina- } \\
\text { cula on Pl.1 }\end{array}$ & 2 & 1 \\
\hline $\begin{array}{l}\text { 9. Uropod 3, } \\
\text { endopodite }\end{array}$ & present & absent \\
\hline 10. Telson & $\begin{array}{l}\text { nearly as long } \\
\text { as wide }\end{array}$ & $\begin{array}{l}\text { strongly } \\
\text { shortened, } 1.5 \\
\text { to } 2 \text { times as } \\
\text { wide as long }\end{array}$ \\
\hline
\end{tabular}

TABLE II

Distribution of plesiomorphic $(\mathrm{O})$ and apomorhic character states (-) over the various N.W. African taxa of the Metacrangonyx group.

\begin{tabular}{|c|c|c|c|c|c|c|c|}
\hline State & Taxon & $M l$ & As & $A l$ & $A p$ & $P y$ & $P m$ \\
\hline 1 & & 0 & 0 & 0 & 0 & - & 0 \\
\hline 2 & & - & - & - & 0 & 0 & $\bullet$ \\
\hline 3 & & $\bullet$ & 0 & - & - & 0 & - \\
\hline 4 & & 0 & - & - & - & - & - \\
\hline 5 & & 0 & 0 & 0 & 0 & 0 & - \\
\hline 6 & & 0 & 0 & 0 & 0 & 0 & - \\
\hline 7 & & 0 & • & $\bullet$ & 0 & 0 & - \\
\hline 8 & & 0 & 0 & $\bullet$ & 0 & 0 & $\mathrm{O}$ \\
\hline 9 & & $\mathrm{O}$ & 0 & $\mathrm{O}$ & 0 & $\bullet$ & $\mathrm{O}$ \\
\hline 10 & & 0 & $\bullet$ & $\bullet$ & $\bullet$ & $\bullet$ & $\bullet$ \\
\hline
\end{tabular}

The character states are listed in table I. The taxa are abbreviated as follows: $M l=$ Metacrangonyx longipes; $A s=$ Afrocrangonyx spinicaudatus; $A l=A$. longicaudus; $A p=A$ panousei; $P y=$ Pygocrangonyx repens and $P$. remyi; $P m=$ Pachypodacrangonyx maroccanus. 


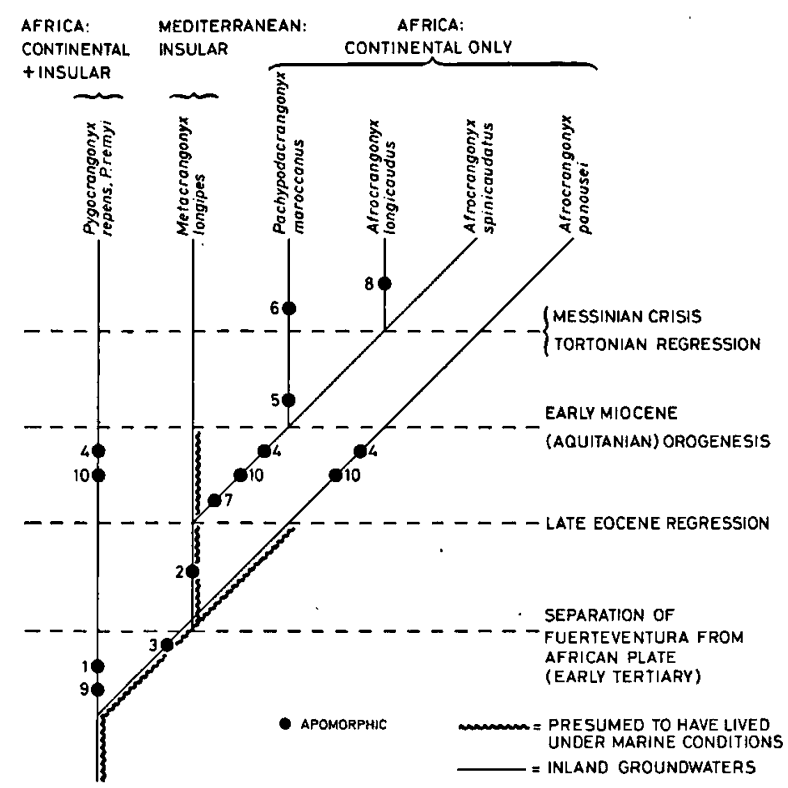

Fig. 13. Cladogram based on 10 character states (see tables I and II) of the N.W. African taxa of the Metacrangonyx group. Note that Pygocrangonyx and Pachypodacrangonyx each have 2 autapomorphic states, Afrocrangonyx longicaudus has 1 autapomorphic state and the remaining taxa only have synapomorphies. Furthermore, the species usually classified as Afrocrangonyx do not form one coherent branch, which weakens the taxonomic value of this genus. A tentative correlation between the branching points in the cladogram and a geological scenario is also proposed.

sinaicus Ruffo, 1983, from outside the N.W. African region, is not included in our analysis.

From this cladogram it may be concluded that Pygocrangonyx and Pachypodaciangonyx are well-characterized genera, the former showing autapomorphies in character states 1 and 9, the latter in states 5 and 6 . Afrocrangonyx panouse $i$ and $A$. spinicaudatus are devoid of autapomorphies, just like Metacrangonyx longipes.

The cladogram also shows that all character states, except for 4 and 10, are free of internal parallelisms. States 4 and 10 arise in all lines, but for the Metacrangonyx branch. A possible explanation for this is that Metacrangonyx could evolve only in the Neogene, after the Aquitanian orogenesis, during which a ridge was formed connecting N.W. Africa with southern Spain and the Balearic islands (Rögl \& Steininger, 1983: 144). Much of Mallorca disap- peared under seawater during the next geological epoch, the Burdigalian transgression (Pomar et al., 1985). This means that the ancestors of Metacrangonyx lived for a longer period in seawater than the ancestors of any of the other members of the group that are supposed to have adapted to inland groundwaters in various stages of the Palaeogene. As point of fact, the only recent member of the genus Metacrangonyx, $M$. longipes, is still the most halophilous taxon of the group. This seems to lead to the conclusion that the independent development of character states 4 and 10 in all taxa but for Metacrangonyx is linked to the transition into more inland, less salty groundwaters.

The scenario for the evolution of the Metacrangonyx group is based on the assumption that the group is of vicariant marine origin. Not necessary is any assumption of colonization through dispersal by limnic ancestors of areas that ran dry during subsequent sea-level regressions in the Tertiary.

Table III finally shows the salient differences between the two known species of Pygocrangonyx, and their state of plesio- and apomorphy. $P$. remyi from N.W. Morocco and $P$. repens from Fuerteventura are each plesiomorphic in two of the character states, and apomorphic in the two others. No conclusion can be drawn as to the question whether the species from the Canary Islands or that from the African continent is closer to the common ancestor.

\section{TABLE III}

Salient differences between the two species of Pygocrangonyx and the states of plesio- and apomorphy. $(\mathrm{M}=P$. remyi from Morocco; $\mathrm{F}=P$. repens from Fuerteventura.)

\begin{tabular}{lll}
\hline & plesiomorphic & apomorphic \\
\hline $\begin{array}{l}\text { 1. Armature } \\
\text { exopodite } \\
\text { uropod 3 }\end{array}$ & $\begin{array}{l}\text { many long spines } \\
(\mathrm{M})\end{array}$ & $\begin{array}{l}\text { one short spine } \\
\text { (F) }\end{array}$ \\
$\begin{array}{lll}\text { 2. Armature distal } \\
\text { margin telson }\end{array}$ & with spines (M) & with setae (F) \\
$\begin{array}{l}\text { 3. Lobation basis } \\
\text { P5-P7 }\end{array}$ & strong (F) & very weak (M) \\
$\begin{array}{l}\text { 4. Armature distal } \\
\text { margin inner } \\
\text { lobe maxilliped }\end{array}$ & setae (F) & with setae only \\
\end{tabular}




\section{Geology}

Two alternative theories are in existence as to the geological origin of Fuerteventura: Dietz \& Sproll (1970) suggest that the island is a sialic fragment of the African plate, separated in the early Cenozoic, whereas Gasteri (1973) supposes that the oldest rocks on the island, the socalled basal complex, may be an uplifted portion of the Atlantic ocean floor. Seismic evidence suggests that general uplift began in the early Eocene (Watkins \& Hoppe, 1979), but earlier localized uplift is probable (Robertson \& Bernoulli, 1982). The earliest submarine volcanic rocks on Fuerteventura were erupted possibly in latest Cretaceous, but more probably in early Tertiary times, into waters that were already relatively shallow (Robertson \& Stillman, 1979).

Whatever theory is right is relatively immaterial to our biogeographic considerations. It is clear that Fuerteventura has existed as an independent island since the early Tertiary, irrespective if it was an African plate fragment or a de novo uplifted part of the ocean floor. At any rate, it is clear that the island could not have developed any freshwater stygofauna before it emerged for the last time above sea level, and geological evidence is undisputed that it was below sea level in the late Mesozoic.

It appears to be significant in this context that all three localities from which Pygocrangonyx repens is known lie in the central-western part of Fuerteventura, thus all inside a relatively small basal complex zone consisting of the island's oldest, pre-Miocene, rocks (Robertson \& Bernoulli, 1982; cf. fig. 14). This suggests that the progenitors of $P$. repens evolved from some marine stock through vicariance during the uplift of this area.

The second species of Pygocrangonyx, P. remyi, is known from a spring at an altitude of $1280 \mathrm{~m}$ in the southwestern part of the High Atlas in Morocco (Jjoukak, ca. $95 \mathrm{~km}$ S.S.W. of Marrakech on the road to Taroudannt). Several authors suppose that tectonic movements along the south Atlas could have affected a narrow linear zone on Fuerteventura, although this

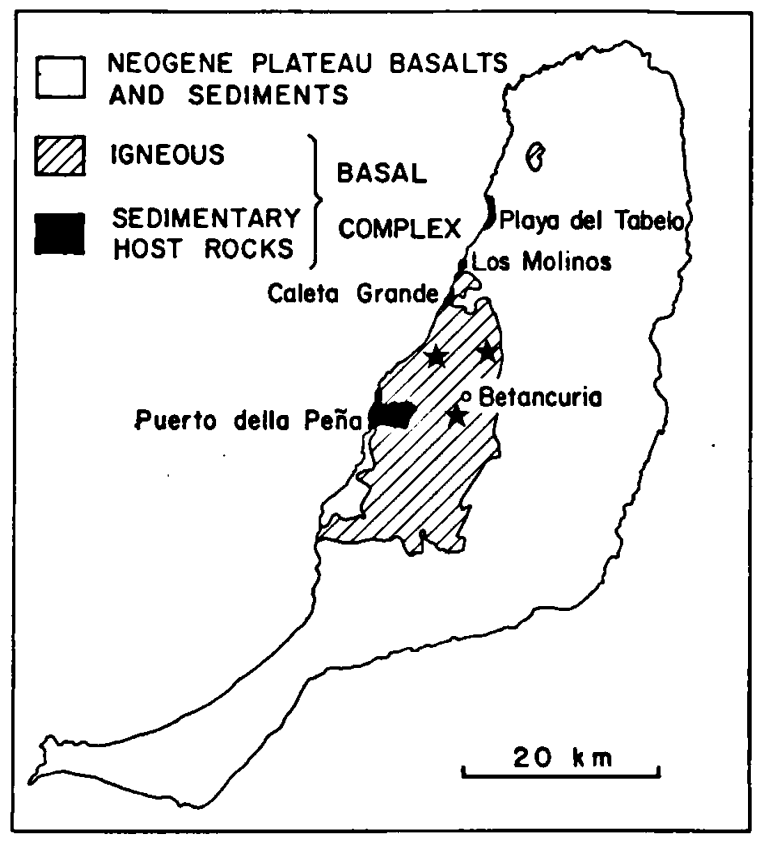

Fig.14. Outline geological map of Fuerteventura (after Robertson \& Bernoulli, 1982) to show the location of the basal complex (= the oldest rocks on the island) and the stations in which Pygocrangonyx repens was found (indicated with an asterisk).

structural link is not confirmed by other authors (refs. in Robertson \& Bernoulli, 1982: 519-520). The biogeographic evidence (one species of Pygocrangonyx localized in the basal complex region of Fuerteventura, another in the S.W. part of the High Atlas) is suggestive of the existence of a structural link. We believe, however, that the model in which Fuerteventura represents a fragment of the African plate forms the most parsimonious explanation for the insular/continental distribution of Pygocrangonyx. The remaining species of the Metacrangonyx group occur at considerably smaller distances from the seacoast, which may also be an indication for an older age of Pygocrangonyx remyi.

\section{Correlation of cladistic and geological data}

We assume that the cladogram of fig. 13 is correlated with geological events in the distribution area of the Metacrangonyx group. Pygocrangonyx is the oldest offshoot, the origin of which can be 
related to the separation of the Fuerteventura fragment from the African plate (and/or, if we believe the view of certain geologists, to the structural link between the south Atlas and Fuerteventura). Both events are supposed to have taken place in the early Tertiary. At any rate, the autapomorphous states 1 and 9 shared by both the insular taxon (repens) and the continental one (remyi) must have been acquired before the interruption of the gene-flow between Fuerteventura and the continent.

Subsequently, the Moroccan genus Pachypodacrangonyx evolved. According to the scenario proposed by Boutin \& Messouli (in press) for this genus, its origin corresponds with the withdrawal of the sea after the Eocene transgression in the area W. and S.W. of Marakkech.

The Messinian sea-level drop, and the subsequent re-opening of the Mediterranean after the salinity and desiccation crisis, resulted in the final differentiation between Metacrangonyx, Pachypodacrangonyx, and the forms classified as Afrocrangonyx.

\section{ACKNOWLEDGEMENTS}

The fieldwork in Fuerteventura has been supported by a grant from the Treub Maatschappij, Utrecht.

We are indebted to Dr. C. Boutin, Marrakech, and Professor H. U. Schmincke, Bochum, for valuable information about publications dealing with the geology of Fuerteventura. Professor S. Ruffo (Verona) and Dr. G. S. Karaman (Titograd) are thanked for the loan of the typematerial of various species of the Metacrangonyx group.

\section{REFERENCES}

Balazuc, J. \& S. Rufro, 1954. Due nuove specie del genere Metacrangonyx Chevreux (AmphipodaGammaridae) delle acque interne del nord Africa francese. Memorie Mus. civ. Stor. nat. Verona, 4: 25-33.

Bou, CL., 1975. Les méthodes de récolte dans les eaux souterraines interstitielles. Annls. Spéléol., 29 (4) "1974": 611-619.

Bousfield, E. L., 1977. A new look at the systematics of gammaroidean Amphipoda of the world. Crustaceana, Suppl. 4: 282-316.

,-- 1982 . Amphipoda. In: S. P. PArker ed., Synopsis and classification of living organisms: 254-293 (McGraw-Hill, New York).
Boutin, C. \& M. Messouli, in press. Pachypodacrangonyx maroccanus, n. gen., n. sp., nouveau représentant du groupe Metacrangonyx dans les eaux souterraines du Maroc. Crustaceana, Suppl. 12.

Chevreux, E., 1909. Amphipodes (première série). Archs. Zool. exp. gén., (5) 2 (Biospeologia, 12): 27 49 , pls. I-II.

Delamare Deboutteville, Cl., 1960. Biologie des eaux souterraines littorales et continentales. Actualités scientifiques et industrielles, 1280: 1-740 (Hermann, Paris).

Dietz, R. S. \& W. P. Sproll, 1970. East Canary Islands as a microcontinent within the Africa-North America continental drift fit. Nature, 226: 1043-1045.

Evers, A., K. Klemmer, I. Müller-Liebenau, P. OHм, R. Remane, P. Rothe, R. zur Strassen \& D. Sturhan, 1970. Erforschung der mittelatlantische Inseln. Umschau, 1976 (6): 170-176.

GASTERI, P., 1973. Is the Betancuria massif, Fuerteventura, Canary Islands, an uplifted piece of oceanic crust? Nature, 246: 102-104.

Karaman, G. S., 1981. Revision of genus Metacrangonyx Chevr. 1909. Glasn. rep. Zav. Zašt. Prir. prir. Muzeja Titograd, 14: 31-46.

Karaman, G. S. \& J. L. Barnard, 1979. Classificatory revisions in gammaridean Amphipoda (Crustacea), 1. Proc. biol. Soc. Wash., 92: 106-165.

Pomar, I., J. J. Fornos \& A. Rodriguez-Perea, 1985. Reef and shallow carbonate facies of the Upper Miocene of Mallorca. Sixth Eur. Meet. int. Assoc. Sedimentol., Excursion guide book: 495-518 (Inst. Estudis Ilerdencs, Lleida).

Robertson, A. H. F. B. D. Bernoulli, 1982. Stratigraphy, facies, and significance of Late Mesozoic and Early Tertiary sedimentary rocks of Fuerteventura (Canary Islands) and Maio (Cape Verde Islands). In: U. von RaD, M. SARntheim \& E. Seibold eds., Geology of the Northwest African continental margin: 498-525 (Springer, Berlin/Heidelberg/New York).

Robertson, A. H. F. \& C. J. Stillman, 1979. Submarine volcanic and associated sedimentary rocks of the Fuerteventura basal complex, Canary Islands. Geol. Mag., 116: 203-214.

Rögl, F. \& F. F. Steininger, 1983. Vom Zerfall der Tethys zu Mediterran und Paratethys. Die neogene Paläogeographie und Palinspastik des zirkummediterranen Raumes. Annln. naturh. Mus. Wien, (A) 85: 135-163, Taf. 1-14.

Ruffo, S., 1983. Une nouvelle espèce de Metacrangonyx Chevreux (Amphipoda: Gammaridae) du désert de Sinai. Isr. J. Zool., 31: 151-156.

Sahellenberg, A., 1937. Die Amphipodengattungen um Crangonyx, ihre Verbreitung und ihre Arten. Mitt. zool. Mus. Berlin, 22 (1): 31-44.

Scrmincke, H. U., 1976. The geology of the Canary Islands. In: G. KunkeL ed., Biogeography and 
ecology in the Canary Islands: 67-184 (Junk, The Hague).

Stock, J. H., 1977. The taxonomy and zoogeography of the hadziid Amphipoda with emphasis on the West Indian taxa. Stud. Fauna Curaçao, 55 (177): 1-130.

Valdecasas Huelin, A. G., 1985. Estudio faunistica de la cueva submarina "Tunnel de la Atlantide", Jameos del Agua, Lanzarote. Naturalia hisp., 27: $1-56$.

Watkins, J. S. K. W. Hoppe, 1979. Seismic reflection reconnaissance of the Atlantic margin of Morocco. In: M. TAlwani, W. Hay \& W. B. F. Ryan eds.,
Deep drilling results in the Atlantic Ocean: continental margins and paleoenvironments. Maurice Ewing Ser., 3: 205-217 (Amer. geophys. Union, Washington D.C.).

Wilkens, H. * J. Parzerall, 1974. Die Oekologie der Jameos del Agua (Lanzarote). Zur Entwicklung limnischer Höhlentiere aus marinen Vorfahren. Annls. Spéléol., 29 (3): 419-434.

Wilson, C. B., 1932. The copepods of the Woods Hole region Massachusetts. Bull. U.S. natn. Mus., 158: i-xix, 1-635, pls. 1-41.

Received: 14 February 1986 